DOI: 10.34015/2523-4552.2020.4.09

УдК 340.15:347.961

Чижиков О. О., аспірант Таврійського національного університету імені В. І. Вернадського e-mail: chyzhykov86@gmail.com ORCID: 0000-0001-8248-1159

\title{
ІСТОРИКО-ПРАВОВИЙ АСПЕКТ РОЗВИТКУ ЗАКОНОДАВСТВА ПРО ПРОТОТИПИ ОРГАНІВ, ЩО ЗДІЙСНЮВАЛИ НОТАРІАЛЬНУ ДІЯЛЬНІСТЬ НА ЗЕМЛЯХ РУСІ ТА В МОСКОВІЇ
}

У статті здійснено ретроспективний аналіз нормативно-правових положень, які врегульовували первісну нотаріальну діяльність. Розглянуто окремі положення Руської Правди, як базисного акту давньої Русі, а також такі документи Галицько-Волинського князівства - Грамоту князя Івана Ростиславовича (1134р.), «Рукопісаніє» князя Володимира Васильовича (1287р.), Уставну грамоту Мстислава Романовича (1289 р.). Надано огляд наукової літератури та правових актів, у яких згадується протореєстраційна діяльність та складання окремих актів приватно-правового характеру так званими майданними піддячими (або скорописцями) в Московії.

Ключові слова: нотаріат; нотаріальна діяльність; майданні піддячі; історія нотаріату.

В статье осуществлён ретроспективный анализ нормативно-правовых положений, которые регулировали первичную протонотариальную деятельность на северных землях Руси. Рассмотрено отдельные положения Русской Правды, как базисного акта древней Руси, а также такие документы ГалицкоВолынского княжества как Грамота князя Ивана Ростиславовича (1134 г.), «Рукописание» князя Владимира Васильевича (1287 г.), Уставная грамота Мстислава Романовича (1289 г.). Представлен обзор научной литературы и правовых актов, в которых упоминается проторегистрационная деятельность и составление отдельных актов частно-правового характера так называемыми площадными подьячими (или скорописцами) в Московии.

Ключевые слова: нотариат; нотариальная деятельность; площадные подьячьи; история нотариата.

Постановка проблеми. Аналізуючи різноманітні роботи у сфері юриспруденції, бачимо, що вивчення історичної складової того чи іншого правового явища чи питання, стало традиційним кроком для більшості дослідників. Дійсно, знання про причини виникнення певного положення сучасного нормативно-правового акту, умови його формування та еволюції, причини, через які такий припис, можливо, було виключено 3 текстів відповідних документів, дозволяє 
більш повно зрозуміти суть чинного законодавства, не тільки його історичну, але й правову природу, соціальне підгрунтя й логічну обумовленість існування в сучасному світі. До того ж, часто історичні приписи $є$ просто цікавими, а подекуди й незвичними для сприйняття сучасного юриста.

Як приклад зміни поглядів та уявлень в історичній ретроспективі варто навести цитату I. Є. Нєймана, який у роботі «Початкові підстави кримінального права» 1814 р. писав: «кримінальне право у власному смислі або закони про злочини й покарання за них розділяються на дві головні частини: перша містить правила про злочини та призначувані за них покарання взагалі; друга має предметом положення про різні злочини та покарання, визначене за кожен із них. Перша з цих частин називається в навчальних книгах загальною, а друга - особливою частиною (курсив - I. Є. Нєймана) кримінального права; але вирази ці самі по собі неясні та не введені в інші мови освічених народів крім німецького, залишені нами як зайві технічні слова» (курсив наш - О. Ч.) [6, С. 7-8].

Тобто, більше двохсот років тому дослідник-криміналіст уважав загальну та особливу частини кримінального права «зайвими технічними словами», а більшість нинішніх правників навряд чи представляє, як може бути інакше, принаймні в нашій правові традиції.

Постановка завдання. У цій статті ми спробуємо проілюструвати розвиток законодавства, яка врегульовувало первісні процедури, суб'єктний склад, організаційні та правові форми діяльності, схожої 3 нотаріальною діяльністю. До- слідження спиратиметься на роботи XIX - першого десятиліття XX століття, які містять положення нормативних актів і правозастосовних документів, оригінали яких у своїй більшості об'єктивно недоступні сучасному дослідникові.

Аналіз останніх досліджень i публікацій. Нами проаналізовано роботи 3 обраної тематики таких сучасних правників як Ю. Ю. Бисага, І. П. Фріс, М. Б. Булгаков, О. А. Обухов, а також дослідників XIX - початку ХХ століття: $\quad$ М. Ф. Злотнікова, П. Д. Калмикова, Л. Б. Мандельштама й інших учених.

Виклад основного матеріалу. П. Д. Калмиков, який досліджував окремі питання становлення нотаріальної діяльності на землях, поневолених Російською імперією, у своїй доповіді про символізм права взагалі та російського зокрема, зазначає, що право, як сукупність ідей, якими люди керуються в своєму житті, у безлічі взаємовідносин, мають корінну основу в свідомості цих людей, у загальному настрої та спрямованості їхньої розумної волі. У свідомості зароджуються юридичні істини, але вони не залишаються загальними поняттями, а розкриваються в безлічі зовнішніх діянь. Так, на думку вченого, виникають форми та обряди юридичні. Він наголошує, що в первісному стані розвитку суспільства та суспільних відносин людина, для вираження своїх думок у мові, звертається до чуттєвих образів. Ще більше відчутним таке звернення $є$ у праві. Наприклад, під час укладання договорів, пов'язаних із майном, при здійсненні різноманітних угод у сімейному та цивільному житті, люди були схильні наділяти юридичні поняття, які слу- 
гували основою цих явищ, у видимі предмети, які найбільше впливають на відчуття, через що вони стають символами цих понять. Юридичні поняття виражаються не абстрактно в простих і мінімально необхідних формах, а в грубих матеріальних шатах. Так, наприклад, для розв'язання спору про власність на землю, до суду приносили глибу землі й розгляд справи здійснювався над нею; для означення передачі володіння відчужувач насипав землю в полу вбрання набувачеві; для закріплення своєї згоди сторони ламали палицю або соломину й кожен зберігав у себе свою частину протягом всього часу існування 30бов'язання до того моменту, поки з'єднання обох обломків не стане знаком його виконання $[4$, с. 11,12 , 13-14].

Не менш колоритним і символічним було становлення каральних приписів, які стали фундаментом подальшого розвитку матеріального та процесуального кримінального права, що також підкреслює значення історичного аналізу розвитку кримінальної відповідальності за ті чи інші діяння.

У науковій літературі беззаперечним часом виникнення нотаріальної діяльності прийнято вважати Римську імперію як колиску римського права, яке створило міцні підвалини для сучасної європейської цивілістики. На Русі ж, на думку Ю. Ю. Бисаги, складання письмових актів при укладенні правочинів було виключним явищем. Учений зазначає, що в Руській Правді немає жодної вказівки на письмові документи як на докази існування юридичних відносин. Він наголошує, що перші письмові правочини в Україні-Русі починають з'являтися в період феодальної роздробленості в XII столітті, наводячи прикладами окремі уставні та жалувані грамоти удільних князів, а також деякі окремі документи приватних осіб, основним змістом яких було засвідчення купівлі та продажу прав на землю та людей (холопів).

Щодо відповідних документів Галицько-Волинського князівства, то автор до них відносить Грамоту князя Івана Ростиславовича (1134р.), «Рукопісаніє» князя Володимира Васильовича (1287р.), «Уставну грамоту» Мстислава Романовича (1289 р.). Абсолютно справедливим вважаємо висловлене твердження, що органи нотаріату на території сучасної Україні за часів Київської Русі зобов'язані своїм становленням перш за все економічним процесам розширенню торговельної діяльності та збільшенню обігу в галузі торгівлі. Усна форма правочину вже не відповідала потребам часу. Заповнити ж потребу в складанні документів у письмовій формі змогли так звані дяки та піддячі. Спочатку це були особи професії, яка носила вільний характер, а 3 розвитком приказної системи стали обов'язковими членами органів держави, вони мали беззаперечний вплив на хід судових і адміністративних справ, про що ми деталізуємо нижче за допомогою конкретних прикладів, описаних у літературі.

Головним завданням дяків та їхніх помічників-піддячих було ведення діловодства в громадських установах, також вони займалися складанням і підписанням грамот, видачею оригіналів, копій документів і довідок. Також дяки виконували і нотаріальні функції, які їм були надані відносно нерухомості 
(XIII століття). Паралельно з приказними дяками в XIV столітті було створено інститут майданних піддячих, які складали письменні акти в містах $[1$, с. 18].

Далі в указаній публікації автор переходить до періоду поглинання Московською державою українських земель, справедливо наголошуючи на московській політиці нівелювання відмінностей у правовому регулюванні суспільних відносин і діяльності державних інституцій.

Утім, на наш погляд, для правильного розуміння місця нотаріальної діяльності в Україні та становлення кримінальної відповідальності за порушення в цій сфері, необхідно розглянути відмінності, які існували на той момент у московських i українських землях.

Також, не піддаючи сумніву значущість наведених Ю. Ю. Бисагою доводів, маємо все ж таки зазначити, що навряд чи коректно буде говорити саме про створення інституту майданних піддячих. Наукові роботи XIX - початку $\mathrm{XX}$ століття, автори яких мали можливість опрацювати ще наявні на той час історичні документальні джерела, які, нажаль, не завжди збереглися у вирі трагічних подій XX століття, дають зрозуміти, що самі майданні піддячі, а в подальшому їхні об'єднання, були не результатом вольової креації, а стали відповіддю на еволюцію суспільних відносин і вимог часу, коли виникала потреба складання та/або засвідчення певного документу, а наявні державні інституції не могли запропонувати адекватної процедури для задоволення цих потреб.

Абсолютно коректною в цьому контексті, на наш погляд, є характе- ристика майданних піддячих Л. Б. Мандельштама, який називає їх «ембріональним зачатком того органу публічної діяльності, який з часом вилився в форму нотаріату» [5, с. 2627].

Узагалі ж, зважаючи на оплатну основу надання вказаних послуг, тут також спрацювали й певні економічні правила. Коли виникла потреба, почав формуватися обсяг попиту, бажання отримати певну послугу, наявність можливості оплатити ї̈ вартість і згода оплатити iii y запропонованому розмірі. Відповідно, попит і продиктував пропозицію - спроможність надати послугу та готовність надати іiї за ціну, яка б влаштувала клієнта. Логічно, а якщо оцінювати ці події 3 висоти наших знань про розвиток суспільств і держав, то й цілком традиційно, що приватна ініціатива виявилася набагато гнучкішою за державну й протонотаріальні дії почали виконувати особи, які мали для цього певні знання та навички, у порядку особистої недержавної ініціативи. Держава пізніше взяла таку діяльність під свій контроль.

Так, наприклад, О.А. Обухов пов'язує початок переходу в Московській державі від усного регулювання юридично значимих фактів і процедур до письмової форми, яка потребувала вчинення визначених реєстраційних дій визначеними особами, з указом царя Федора Івановича від 15 грудня 1597 р. Цим документом передбачалося «повні докладні, купчі, кріпості й кабали писати в холопському приказі у книгах». Книги ж ці належало зберігати спеціальним особам - дякам. Учений вважає цей маркер наступним після неписьмового звичаєвого та обрядо- 
вого регулювання етапом розвитку нотаріату [7, с. 19]. На наш погляд, наведене є цікавим не стільки з позиції розвитку нотаріату, бо вказані протореєстраційні дії приказних дяків із великою натяжкою можна назвати нотаріальними, а 3 чітко оформленим бажанням держави взяти під контроль і саме здійснення вказаних дій, і зберігання цих документів. На цю тенденцію звертав увагу й І. П. Фріс у своїй кандидатській дисертації, присвяченій вивченню питань кримінально-правового забезпечення охорони нотаріальної діяльності в Україні. Так він зазначає, що із часом втручання влади в діяльність майданних піддячих стало більш активним. Було офіційно визначено органи, які повинні були здійснювати контроль за їхньою діяльністю. Це було доручено робити приказам, що відали конкретним майданом. Прикладом для контролю майданних Іванівської площі (тобто майдану, який виник на території московського кремля в 1329 р. після будівництва кам'яної церкви Івана Ліствичника, через що площа й отримала таку назву) автор наводить Помісний приказ, який призначав конкретну особу - старосту, котрий і здійснював безпосередній контроль $[8$, c. 87].

До слова, М. Ф. Злотніков ще на початку $\mathrm{XX}$ століття здійснив спеціальне дослідження, присвячене піддячим саме Іванівської площі в контексті історії нотаріату Московії. Так, дослідник указував, що приблизно 3 середини XVI століття на Московщині існував доволі своєрідний інститут майданних піддячих, що виконував (до кінця XVII століття) головним чином окремі нотаріальні функції в формах, які відповідали тому часові. Також у вказаній роботі зазначається, що нотаріат, як установа, з'являється на Заході та в Росії доволі пізно, коли народ досягає певної стадії державного та культурного розвитку. Зазвичай цьому періодові передує тривалий час, коли одна 3 основних функцій нотаріусів - писання приватних юридичних актів надається всім охочим. Так, у ранню епоху ці акти могли писати всі, хто знав грамоту. У Московії такими особами переважно були представники духовенства, церковний причет і приказні люди - дяки та їхні помічники піддячі, котрі обіймали різні адміністративні посади. Із кінця ж XVI століття починають зустрічатися відомості, що написання всіляких приватних актів $\epsilon$ спеціальним заняттям деяких людей, котрі, як тоді говорили, «годувалися пером». Такі особи мали різні назви: писчик, майданний писчик, майданний дячок, піддячий з площі, майданний піддячий, писчий підьячишко. Майданними вони називалися за місцем своєї роботи - на майдані (площі). Разом із тим, наряду 3 цими професійними писарями, письмові акти продовжували складати й інші писемні особи. Проте, ці писарі-професіонали заклали підвалини інституту майданних піддячих, який зазнав значного розповсюдження та важливого значення вже в XVII столітті. М.Ф.Злотніков виокремлює в його історії, як історії нотаріату, два періоди: до та після Уложення 1649 р. У перший період «майдан», який склався історично, займався писанням актів наряду з іншим установами та окремими особами. Утім, майданна діяльність потроху набувала панівного становища щодо 
складання актів, хоча акти, які складалися на площах майданними виконавцями, ще нічим не відрізнялися від інших. Роль і значення «майдану» значно виросли саме з часу Уложення 1649 р., коли йому офіційно було доручено складання важливіших актів, чим узаконювався вже існуючий у різних місцях звичай. Таким чином «майдан» став органом, який виконував нотаріальну функцію 3 іншим, ніж раніше значенням. Разом із цими змінами зросло й значення самого майданного акту. Учений зазначає, що саме $з$ цього часу починається другий період у історії інституту майданних піддячих, що продовжувався до реформи царя Петра I, яка почалася наприкінці XVII та тривала до початку XVIII століття [3, c. 3-5].

Також автор наводить приклади різних документальних актів, що складалися професійними писарями, які переважно були майданними піддячими, а більшість із них піддячими, які працювали саме на Іванівській площі в Москві. Значна частина наведених актів складалася з «купчих» і «кабал», у тому числі «закладних кабал». У купчих засвідчувалися угоди купівлі-продажу. Під кабалами мається на увазі не форма особистої залежності, а широкий спектр документів, якими оформлювалися боргові зобов'язання. Наприклад, за допомогою згаданих закладних кабал засвідчувалися угоди про залог нерухомого майна. Також існували кабали в грошах або «у сріблі», тобто розписки про позику грошей; ростові кабали - на виплату відсотків за позикою; служилі кабали - коли відсоток за позикою сплачувався у формі служби або виконання якихось робіт; вірчі кабали - ними забезпечувалися підстави звернення поручителя до боржника щодо стягнення боргу, який він сплатив за нього в рамках свого поручительства тощо.

Іноді попадалися збережені на той час «данні», які посвідчували дарування майна або його передачу на виконання іншою стороною певних зобов'язань перед таким дарувальником, наприклад, прийняття його до монастиря або поховання дарувальника - світської особи на території монастиря після смерті.

Із другої половини XVI століття фіксуються відомості про існування майданних піддячих і в інших місцевостях: Новгороді (1567 р.), Твері (1573 р.), Переяславлі-Залєському (1585-1586 рр.), Пскові (15911592 рр.), Івангороді (1593 р.) [3, с. 9]. Наприклад, М. Б. Булгаков за результатами аналізу окремих документів, направлених майданними піддячими, яких учений називає «скорописцами», на адресу царя, описує структуру їхніх об'єднань у Пскові [2, с. 6768]. Слід зазначити, що вона мала зрозумілу структуру з певними корпоративними ознаками, принципами взаємовідносин із державою в особі стольника й воєводи та дяка, які розміщувалися в регіональному центрі - місті Новгороді. Разом із тим, організація, яка об'єднувала майданних піддячих, була невеликою, про що свідчать розміри річної плати державній казні за право займатися такою діяльністю, а саме 2026 рублів на рік.

Відомості про майданні організації Москви, представники яких працювали на інших, крім Іванівської, площах, були віднайдені М. Ф. Злотніковим за 1649 р. - купча, писана піддячим Двірцевої площі 
Офонкою Федоровим і за 1660 р. сказка (тобто список осіб, які підлягали обкладенням подушною податтю - поголовщиною), складена піддячим Троїцької площі Івашкою Тимофєєвим.

Із другої половини XVII століття паралельно 3 майданними організаціями піддячих, члени яких надавали й протонотаріальні послуги самостійно та були сконцентровані на майданах, існували й інші піддячі, котрі виконували ці ж функції, проте знаходилися при приказах світської та духовної влади: Стрілецького приказу, Розряду, Казанського Палацу, Великого Палацу, Холопського Суду, Великої Казни, Володимирського Судного, Іноземного приказу, Посольського приказу, Патріаршого Розряду, Дворцового патріаршого приказу. За своєю побудовою вони були близькими до загального типу майданних організацій, утім значною мірою відрізнялися від них правами щодо написання актів. I цікавим $€$ те, що їхні права були вужчими порівняно 3 самоврядними майданними організаціями. Так, піддячим при приказах заборонялося писати позикові кабали та інші кріпості, а дозволялося - лише чолобитні та приставні пам'яті, а також записки від суду до суду $[3$, с. 13-14, 16].

Слід також звернути увагу на визнання ролі майданних піддячих і значення їхньої діяльності для тогочасного правозастосування. Так, наприклад, 1630 р. у приказі Великого Палацу слухалася претензійна справа між Кирилівським монастирем (позивач) i . П. Шереметьєвим (відповідач) про спірну землю - село Чіркін Коломенського повіту. Не вдаючись у деталі вказаного процесу, вважаємо за необхідне звернути увагу на такий цікавий момент: представник відповідача, намагаючись підірвати довіру суду до справжності та легітимності документа - «данної» 1574-1575 рр., серед іншого, вказував і на ту обставину, що акт був складеним боярською людиною, а не майданним піддячим, хоча «на вотчиныде данныхъ и никакихъ крепостей боярскимъ людямъ писать не вельно». Далі сторони будують процес доказування на підставі пізнішої данної, «писали-де таковую на Москвђ на площади у Ивана великаго (тобто на Іванівській площі, назва якої й походить від указаної церкви та дзвіниці біля неї, про що ми згадували вище - O. Ч.) площадные подьячіе, а не на городе і не въ сель», підписаної трьома майданними піддячими - записними послухами: Другим Дмітрієвим сином Нілаєвим, Федором Пєрфір'євим сином Павловим і Андрієм Семеновим сином Малого. М.Ф.Злотніков зазначає, що термін «записні» свідчить про те, що вказані майданні піддячі працювали не самі по собі, а належали до майданної організації [3, с. 9-10]. Подальше вивчення матеріалів вказаної справи дає підстави стверджувати, що й позивач, і відповідач, як сторони процесу, не просто безспірно визнавали акти, складені указаними майданними піддячими, а й надавали їм великого значення порівняно з документами, складеними іншими фахівцями, котрі, утім, не входили до складу майданної організації.

Висновки. Отже, підсумовуючи викладене, маємо підстави констатувати, що розвиток суспільних відносин взагалі та ускладнення товарноматеріальних взаємин між різними, не завжди знайомими та близькими 
людьми, спонукало до виникнення та становлення нового інституту в справах документотворення. Специфіка виконання цього виду інтелектуальної праці висувала певні вимоги до їі виконавців. Історична об'єктивність робила цих фахівців наближеними до церковної сфери, що, серед іншого, надавало їм певного авторитету серед споживачів даної послуги, а також певною мірою обгрунтовувало місця знаходження таких фахівців - на торгових майданах біля великих храмів. Подальше зростання ролі скоропис- ців у здійсненні протонотаріальних функцій призвело й до збільшення значення їхньої діяльності для прийняття достовірності та оригінальності створюваних ними приватноправових актів.

Подальше видання вже Петром I указів, які стосувалися написання актів майданними піддячими, а також укази, спрямовані на реформування нотаріальної сфери, фактично завершили епоху «скорописців» як протонотаріального органу.

\section{Список використаних джерел}

1. Бисага Ю. Ю. Історико-правові аспекти виникнення сучасного українського нотаріату. Visegrad Journal on Human Rights. 2014. Вип. 1. С. 18-22.

2. Булгаков М.Б. Псковские площадные подьячие в первой половине XVII в. Псков. Социально-политическая и экономическая история. 2004. Вып. 20. С. 66-69.

3. Злотников М. Ф. Подьячие Ивановской площади. К истории нотариата Московской Руси. Петроград : типография М. М. Стасюлевича, 1916. 50 с.

4. Калмыков П. Д. О символизме права вообще и русского в особенности : речь, произнесённая в торжественном собрании Императорского Санкт-Петербургского университета 31 марта 1839 года. Санкт-Петербург : типография Карла Крайя, 1839. $93 \mathrm{c.}$

5. Мандельштам Л. Б. Учреждение нотариата и его организация. Журнал министерства юстиции. 1899. Вып. 4. С. 1-52.

6. Нейман И. Е. Начальные основания уголовного права. Санкт-Петербург : типография Иос. Иоаннесова, 1814. 75 с.

7. Обухов А.А. Злоупотребление полномочиями частными нотариусами и аудиторами: основания криминализации, проблемы квалификации и дифференциации ответственности : дис. ... канд. юрид. наук: спец. 12.00.08. Нижний Новгород : Нижегородская академия МВД РФ, 2004. 202 с.

8. Фріс І. П. Кримінально-правове забезпечення охорони нотаріальної діяльності в Україні : дис. ... канд. юрид. наук: спец. 12.00.08. Івано-Франківськ : Прикарпатський національний університет імені Василя Стефаника, 2015. 231 с.

\section{References}

Bysaha, Yu. (2014) Istoryko-pravovi aspekty vynyknennia suchasnoho ukrainskoho notariatu. Visegrad Journal on Human Rights, 1, 18-22 [in Ukrainian].

Bulgakov, M. B. (2004). Pskovskie ploshhadny`e pod yachie v pervoj polovine XVII v. Pskov. Soczial `no-politicheskaya i e konomicheskaya istoriya, 20, 66-69 [in Russian].

Zlotnikov, M. F. (1916). Pod'yachie Ivanovskoj ploshhadi. K istorii notariata Moskovskoj Rusi. Petrograd [in Russian].

Kalmy`kov, P. D. (1839). O simvolizme prava voobshhe i russkogo v osobennosti SanktPeterburg [in Russian].

Mandel`shtam, L. B. (1899). Uchrezhdenie notariata i ego organizacziya. Zhurnal ministerstva yusticzii, 4, 1-52 [in Russian]. 
Nejman, I. E. (1814). Nachal'ny’e osnovaniya ugolovnogo prava. Sankt-Peterburg [in Russian].

Obukhov, A. A. (2004) Zloupotreblenie polnomochiyami chastny'mi notariusami i auditorami: osnovaniya kriminalizaczii, problemy` kvalifikaczii i differencziaczii otvetstvennosti (Dis. ... kand. yurid. nauk). Nizhnij Novgorod [in Russian].

Fris, I. P. (2015). Kryminalno-pravove zabezpechennia okhorony notarialnoi diialnosti $v$ Ukraini (Dys. ... kand. yuryd. nauk). Ivano-Frankivsk [in Ukrainian].

O. Chyzhykov, Postgraduate student of the V. I. Vernadsky Taurida National University

ORCID: 0000-0001-8248-1159

\section{Historical and legal aspect of the development of legislation on the prototypes of the bodies that carried out notarial activities in the Rus' and Muscovy}

The article provides a retrospective analysis of the legal regulations that governed the primary protonotarial activity in the northern lands of Russia. Some provisions of the Russkaya Pravda, as a basic act of ancient Russia, as well as documents of the Galicia-Volyn principality are considered: Charter of Prince Ivan Rostislavovich (1134), "Manuscript" of Prince Vladimir Vasilyevich (1287), Charter of Mstislav Romanovich (1289).

A professional review of scientific literature and legal acts is presented, which mentions proto-registration activities and the compilation of individual acts of a private legal nature by the so-called areal clerks (or cursive writers), which were common in the lands of northern Russia, over which Kiev lost its control. The analysis covered the periods before and after the entry into force of the Code of 1649 until the end of the era of cursive writers just before the beginning of the 18th century.

The questions of the symbolism of law in the execution of transactions with land, transactions with property, transactions where the subject were living people were touched upon. The formation of the notary profession as a non-state free and self-governing professional institution is traced. The issues of the activities of areal clerks are considered in detail.

Specific examples of the documents they draw up are given, as well as materials of law enforcement practice. Expansion on the part of the state is illustrated in order to take control of the activities of the first notaries, to curtail and further eliminate their independence and independence from the state and its bureaucracy. The works of the XIX - early years of the XX century are widely used, which contain the provisions of ancient legal acts and documents that are inaccessible to modern researchers.

Keywords: notary; notarial activity; areal scribes; history of notaries. 